\title{
Pathology and Pathogenesis of Severe Acute Respiratory Syndrome
}

\author{
Jiang $\mathrm{Gu}$ and Christine Korteweg \\ From the Department of Pathology and Infectious Disease Center, \\ School of Basic Medical Sciences, Peking (Beijing) University, \\ Beijing, China
}

Severe acute respiratory syndrome (SARS) is an emerging infectious viral disease characterized by severe clinical manifestations of the lower respiratory tract. The pathogenesis of SARS is highly complex, with multiple factors leading to severe injury in the lungs and dissemination of the virus to several other organs. The SARS coronavirus targets the epithelial cells of the respiratory tract, resulting in diffuse alveolar damage. Several organs/cell types may be infected in the course of the illness, including mucosal cells of the intestines, tubular epithelial cells of the kidneys, neurons of the brain, and several types of immune cells, and certain organs may suffer from indirect injury. Extensive studies have provided a basic understanding of the pathogenesis of this disease. In this review we describe the most significant pathological features of SARS, explore the etiological factors causing these pathological changes, and discuss the major pathogenetic mechanisms. The latter include dysregulation of cytokines/ chemokines, deficiencies in the innate immune response, direct infection of immune cells, direct viral cytopathic effects, down-regulation of lung protective angiotensin converting enzyme 2 , autoimmunity, and genetic factors. It seems that both abnormal immune responses and injury to immune cells may be key factors in the pathogenesis of this new disease. (Am J Pathol 2007, 170:1136-1147; DOI: 10.2353/ajpath.2007.061088)

Severe acute respiratory syndrome (SARS) first emerged in China's Guangdong Province in November 2002. During the following 3 months, it spread rapidly across the world, infecting individuals in several countries and thus resulting in the first human pandemic of the 21st century. At the end of the initial epidemic in August 2003, 8096 probable SARS cases had been reported, with a fatality rate of $\sim 10 \%$ (World Health Organization: http://www. who.int/csr/sars/country/table 2004_04_21/en/). Additional sporadic cases occurred in the period between the winter of 2003 and early spring of 2004 (World Health Organization: http://www.who.int/csr/don/archive/disease/ severe_acute_respiratory_syndrome/en/index.html).

A novel coronavirus was identified as the etiological agent of SARS. ${ }^{1,2}$ This virus (SARS-CoV) belongs to a family of large, positive, single-stranded RNA viruses. ${ }^{3}$ Nevertheless, genomic characterization showed that the SARS-CoV is only moderately related to other known coronaviruses. ${ }^{1,3}$ In contrast with previously described coronaviruses, SARS-CoV infection typically causes severe symptoms related to the lower respiratory tract. The virus has been isolated from several animals, including civet cats and raccoon dogs, although neither of these animals is regarded as the true source. ${ }^{4}$ Recently, certain bat species have been reported as potential natural reservoirs. ${ }^{5}$ SARS is transmitted to and among humans by direct contact, droplet, and airborne routes. ${ }^{6}$ Viral isolation from fecal and urinary samples suggests additional routes of transmission. ${ }^{6,7}$

SARS has a characteristic clinical course. Patients present with flu-like symptoms including fever, chills, cough, and malaise. ${ }^{8}$ Approximately $70 \%$ of the patients subsequently suffer from shortness of breath and recurrent or persistent fever, whereas the remaining 30\% show clinical improvement after the first week. ${ }^{6}$ Approximately 20 to $30 \%$ of patients require intensive care treatment including mechanical ventilation. ${ }^{6}$ Increased alanine aminotransferase, lactate dehydrogenase, thrombocytopenia, and lymphopenia have all been frequently detected in SARS patients. ${ }^{6,8-11}$ In patients younger than 60 years of age the estimated fatality rate amounts to $6.8 \%$ and in older patients attains an estimated $43 \% .^{8}$

A number of complete and partial autopsies of SARS patients have been reported since the first outbreak in 2003. The predominant pathological finding in these

\footnotetext{
Accepted for publication January 9, 2007.

Address reprint requests to Jiang Gu, M.D., Ph.D., Professor and Chairman, Department of Pathology, Dean, School of Medical Sciences, Director, Infectious Disease Center, Peking (Beijing) University, 38 Xueyuan Rd., 100083 Beijing, China. E-mail: jianggu@bmcu.edu.cn.
} 
Table 1. Major Pathological Findings in Various Organs and Tissue

\begin{tabular}{|c|c|c|c|}
\hline Organs/tissue & Pathology & $\begin{array}{l}\text { Number } \\
\text { of cases }\end{array}$ & References \\
\hline Respiratory tract & $\begin{array}{l}\text { Diffuse alveolar damage with varying degrees of acute } \\
\text { exudative features including edema and hyaline } \\
\text { membranes, organization, and fibrosis. Macrophagic or } \\
\text { mixed cellular infiltration, multinuclear giant cells, atypical } \\
\text { reactive pneumocytes, and vascular injury. Positive in situ } \\
\text { hybridization signals in pneumocytes, lymphocytes, and } \\
\text { macrophages }\end{array}$ & 63 & $12-16,18-23$ \\
\hline Spleen and lymph nodes & $\begin{array}{l}\text { Lymphocyte depletion in spleen and lymph nodes with } \\
\text { architectural disruption. Splenic white pulp atrophy. Positive } \\
\text { in situ hybridization signals in immune cells }\end{array}$ & 25 & $11-13,15-17,27$ \\
\hline \multirow[t]{2}{*}{ Digestive tract } & $\begin{array}{l}\text { Intestines: no obvious pathological changes/ nonspecific } \\
\text { changes. Depletion of mucosal lymphoid tissue. Positive in } \\
\text { situ hybridization signals in mucosal epithelial cells }\end{array}$ & 19 & $12,13,39,46$ \\
\hline & $\begin{array}{l}\text { Liver: no specific pathological changes. In some cases, } \\
\text { necrosis and evidence of apoptosis }\end{array}$ & 20 & $9,12,13,17,39,48$ \\
\hline Urogenital tract & $\begin{array}{l}\text { Kidneys: acute tubular necrosis, in varying degrees and other } \\
\text { nonspecific features. Positive in situ hybridization signals in } \\
\text { the epithelial cells of the distal tubules }\end{array}$ & 21 & $12,13,15,17,43,44$ \\
\hline Central nervous system & $\begin{array}{l}\text { Edema and degeneration of neurons, several neurons in situ } \\
\text { hybridization-positive }\end{array}$ & 12 & $12,15,42$ \\
\hline Bone marrow & In some cases, reactive hemophagocytosis & 9 & $9,12,25$ \\
\hline Skeletal Muscles & Myofiber necrosis and atrophy, few regenerative myofibers & 13 & $12,44,46$ \\
\hline Adrenal gland & Necrosis and infiltration of monocytes and lymphocytes & 14 & $12,13,15$ \\
\hline Thyroid gland & Destruction of follicular epithelial cells, several apoptotic cells & 5 & 49 \\
\hline Testes & Germ cell destruction, apoptotic spermatogenetic cells & 7 & 45 \\
\hline Heart & Edema and atrophy of myocardial fibers & 22 & $12,13,15,17$ \\
\hline
\end{tabular}

cases was diffuse alveolar damage (DAD). This severe pulmonary injury of SARS patients is caused both by direct viral effects and immunopathogenetic factors. Many important aspects of the pathology and pathogenesis of SARS have not yet been fully clarified. Here, we offer a comprehensive overview of the morphological and histopathological findings present in different organs and cells. In addition, we summarize the most important mechanisms that may play a role in the seemingly complex pathogenesis of this new disease.

\section{Pathology}

Certain organs of SARS victims, such as the lungs and intestines, have been extensively studied, and the pathological lesions of SARS in these organs are fairly well known. By contrast, the pathology of other organs is incompletely described, and imperfectly known. For ease of reference, the major pathological findings for each organ are summarized in Table 1. Table 2 lists the results of ancillary tests that have been used to confirm the diagnosis, including in situ hybridization, immunohistochemistry (IHC) with antibodies against viral antigens, reverse transcriptase-polymerase chain reaction (RTPCR), electron microscopic (EM) examination, and viral culture.

\section{Respiratory Tract}

The pathological findings in the lungs of more than 60 autopsies of SARS cases have been reported. On gross examination, the lungs were edematous and increased in

Table 2. Results of Ancillary Tests, Used to Confirm SARS-CoV Infection in Lung and Intestinal Tissue

\begin{tabular}{|c|c|c|c|c|c|}
\hline Additional test & $\begin{array}{l}\text { Positive test } \\
\text { results/total } \\
\text { tests (lung } \\
\text { tissue) }\end{array}$ & $\begin{array}{l}\text { Positive test } \\
\text { results/total tests } \\
\text { (intestinal tissue) }\end{array}$ & References (lungs) & $\begin{array}{l}\text { References } \\
\text { (intestines) }\end{array}$ & $\begin{array}{l}\text { Longest duration } \\
\text { reported with } \\
\text { positive test results } \\
\text { in lungs/intestines }\end{array}$ \\
\hline RT-PCR & $47 / 55$ & $12 / 23$ & $18,20,22,28$ & 17,37 & 51 days $^{37} / 43$ days s $^{37}$ \\
\hline In situ hybridization & $31 / 67^{*}$ & $18 / 24$ & $\begin{array}{l}13,15,17,22,28-30(23),{ }^{\dagger} 31 \\
32\end{array}$ & $29,30(23),{ }^{\dagger} 31,39$ & 62 days $^{15} / 45$ days $^{39}$ \\
\hline $\mathrm{IHC}$ & $12 / 47$ & 9/11 & $24,28-30(23)^{\dagger}$ & $29,30(23)^{\dagger}$ & 20 days $^{31} / 20$ days $^{31}$ \\
\hline EM & $26 / 38$ & $12 / 20$ & $12,14(29),+15,16,18,22,24$ & $29,39,46$ & 46 days $^{18} / 21$ days $^{39}$ \\
\hline Viral culture & $10 / 23$ & $15 / 27$ & $14(29),{ }^{\dagger} 17,31$ & $14(29),{ }^{\dagger} 17,31,46$ & 20 days $^{16} / 16$ days $^{14}$ \\
\hline
\end{tabular}

For each test, the number of positive cases and the total number of cases are listed.

${ }^{*}$ In 63 SARS cases, the findings on general histopathology have been reported, whereas in 67 cases, the results of in situ hybridization have been reported. This difference is attributable to the fact that some recently published studies have only described in situ hybridization results without reporting general pathology.

tThese results have been published in two different journals. 


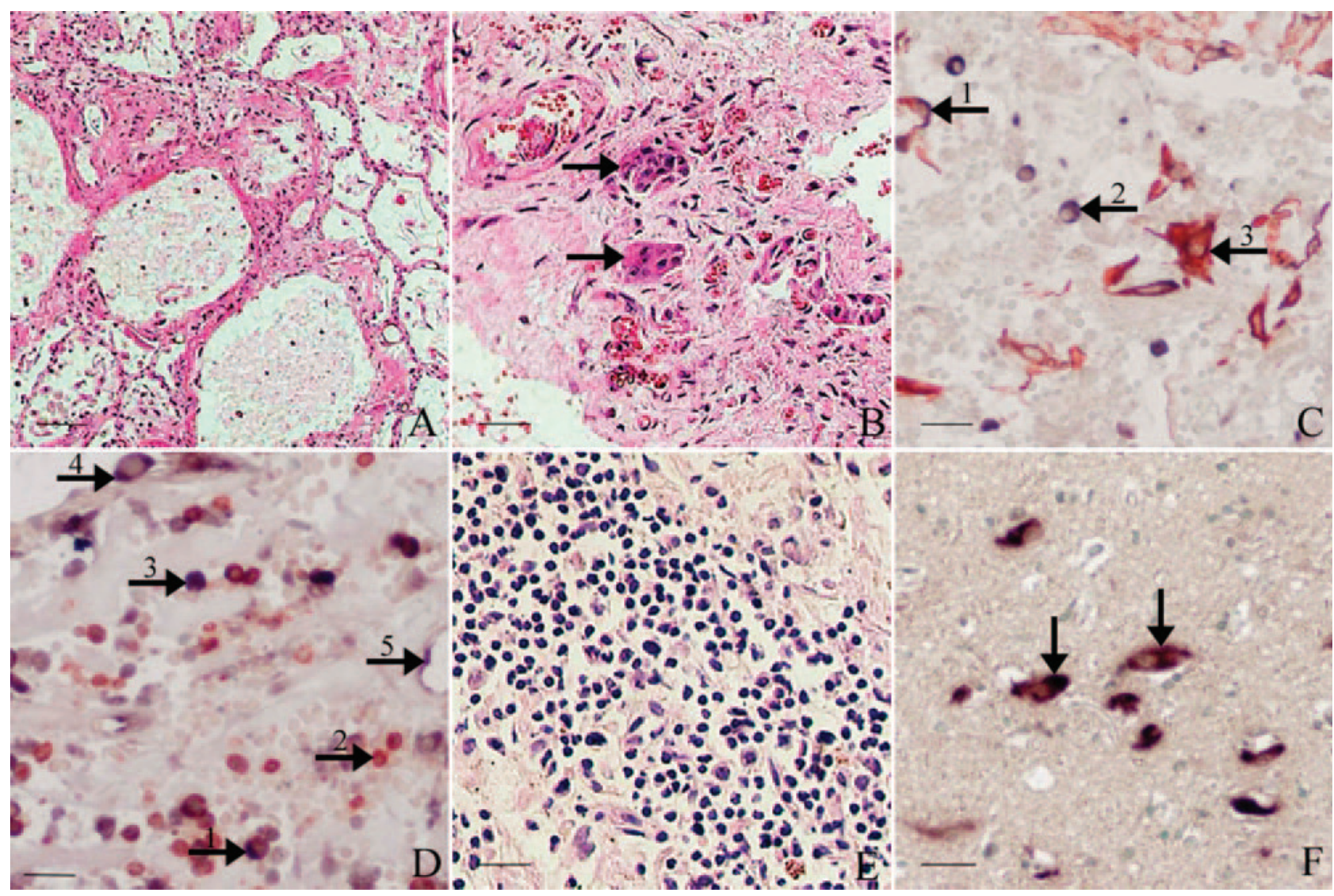

Figure 1. Pathology in the lungs, brain, and spleen. A: Lung tissue of a SARS autopsy showing severe damage, hyaline membrane formation, edema, fibrin exudation, and some inflammatory cells (H\&E staining). Sample from a 50-year-old male SARS patient who died 33 days after disease onset. B: Multinucleated cells (arrows) in the lungs of a SARS patient (H\&E staining). Sample from a 51-year-old male SARS patient who died on day 45 . C: Double labeling combining in situ hybridization (ISH) of SARS viral genomic sequence and IHC with antibodies to cytokeratin (AE1/AE3) showing both brownish red (cytokeratin) and purplish blue signals for viral genome in the same cells, identifying the infected cells as pneumocytes (arrow 1). Arrow 2 points to an ISH-positive and cytokeratin-negative cell (purplish blue signal only), representing an inflammatory cell that is infected by SARS virus. Arrow 3 points to an in situ hybridization-negative pneumocyte (cytokeratin-positive, brownish red signal only) that is not infected by SARS virus. Sample from a 58 -year-old male patient with SARS who died 58 days after disease onset. D: SARS-CoV genomic sequence in various cells in the lungs. Both a dark blue in situ hybridization signal and a brownish red IHC (CD3) signal are present in the same cell (arrow 1), suggesting the infection of T lymphocytes. There are also some uninfected CD3-positive cells (arrow 2, brownish red signal only). Arrow 3 points to in situ hybridization-positive mononuclear cell (purplish blue signal only). A spindle-shaped pneumocyte with a positive in situ hybridization signal is also shown (arrow $\mathbf{4}$, purplish blue signal only). Arrow $\mathbf{5}$ points to an in situ hybridization-positive cell morphologically resembling a vascular endothelial cell (purplish blue signal only). Sample from a 24-year-old male SARS patient who died on day 21 . F: Spleen tissue showing depletion of lymphocytes. Sample from same patient as in C. F: Positive in situ hybridization signals in the cytoplasm of many neurons (arrows) in brain tissue of a SARS patient. Sample from a 49-year-old female SARS patient who died on day 32 . In $\mathbf{C}$, $\mathbf{D}$, and $\mathbf{F}$, in situ hybridization was performed with a 154-nucleotide cRNA probe directed against fragments of the polymerase gene (R1ab) of SARS-CoV. The probe was labeled with digoxigenin, and a NBT/BCIP substrate chromogen kit (Promega Corp., Madison, WI) was used to visualize in situ hybridization signals, resulting in a purplish blue color. In C and D, IHC with antibodies to cytokeratin (AE1/AE3) and CD3 was performed. IHC signals were detected with the HRP reaction kit AEC, which gives a brownish red color. Scale bars: $50 \mu \mathrm{m}(\mathbf{A}) ; 25 \mu \mathrm{m}(\mathbf{B}, \mathbf{C}, \mathbf{E}, \mathbf{F}) ; 20 \mu \mathrm{m}(\mathbf{D})$

weight. $^{12-17}$ In most cases, they showed extensive consolidation. ${ }^{12,14-17}$

Histopathologically, the lungs in SARS characteristically show DAD. During the first phase of the disease (7 to 10 days), SARS lungs display the following features of acute exudative DAD ${ }^{12,13,16,18-23}$ (Figure 1A): 1) extensive edema, 2) hyaline membrane formation, 3) collapse of alveoli, 4) desquamation of alveolar epithelial cells, and 5) fibrous tissue in alveolar spaces. In cases of longer disease duration, features of fibrous organization of DAD appear after $\sim 10$ to 14 days, such as interstitial and airspace fibrosis and pneumocytic hyperplasia. ${ }^{18,20,21,23,24}$ The longer the disease, the more extensive becomes the fibrous organization of the lung tissue. ${ }^{19,20}$ In SARS cases lasting more than 2 to 3 weeks, dense septal and alveolar fibrosis were demonstrated, in addition to organizing features. ${ }^{18,21,23}$ A direct correlation has been found between the extent of fibrosis and the duration of the illness. ${ }^{14,19}$ Pathological changes suggesting active pulmonary injury have been observed up to 108 days after the onset of disease. ${ }^{19}$ Hwang and colleagues $^{19}$ have established a specific pathological pattern in SARS autopsies, characterized by a combination of fibrin balls within airspaces and features of an organizing pneumonia.

In many cases, cellular infiltration has been observed. Immunohistochemical staining has shown that these inflammatory cells predominantly consist of macrophages $^{13,17,22,24,25}$ or a combination of macrophages and lymphocytes with or without neutrophils. ${ }^{12,14-16,18,19,23,26}$ In other cases, however, a disproportionate scarcity of inflammatory cells has been noted. ${ }^{14,15}$ 
Large multinucleated cells have frequently been observed in the lungs of SARS patients (Figure 1B). ${ }^{12,14-16,18-20,23} \mathrm{IHC}$ has identified these cells as macrophages and pneumocytes. ${ }^{14,19,20}$ In addition, atypical enlarged pneumocytes with large nuclei, amphophilic granular cytoplasm, and prominent nucleoli were observed in the majority of SARS patients. ${ }^{14,16,18-20}$ It should be noted, however, that multinucleated cells in the lungs may be the result of many viral or bacterial infections, whereas atypical pneumocytes often appear as a reaction to alveolar damage. Therefore, neither the presence of multinucleated cells or atypical enlarged pneumocytes can be regarded as a unique characteristic of SARS-related pathology.

Additional pathological features include: 1) squamous metaplasia of bronchial and alveolar epithelial cells ${ }^{16,18-20}$; 2) subpleural proliferation of fibrogranulative tissue in small airways and airspaces ${ }^{14}$; 3) loss of cilia of bronchiolar epithelial cells ${ }^{16}$; 4) hemophagocytosis in mononuclear cells residing in pulmonary tissue ${ }^{16}$; 5) apoptosis in epithelial cells, monocytes/macrophages, lymphocytes, and pneumocytes ${ }^{23}$; and 6) vascular injury. Vascular injury consists of edema of the walls of pulmonary vessels and fibrous thrombi with or without pulmonary infarction. ${ }^{12,13,16,18-20}$

In a number of SARS cases, co-infections have been reported. ${ }^{17,19}$ These include infections by Aspergillus species, Mucor species, Pseudomonas aeruginosa, Klebsiella species, methicillin-resistant Staphylococcus aureus, $\alpha$-hemolytic Streptococcus species, and cytomegolavirus. These co-infections are probably related to longer disease durations and/or treatment with high doses of corticosteroids. ${ }^{19}$

Certain studies have compared the pulmonary pathology of SARS cases with non-SARS cases showing SARSlike symptoms. ${ }^{15,17,20}$ Thirty-six of 36 SARS autopsies showed DAD, contrasting with only 19 of 40 of such non-SARS cases. Apart from prominent vascular injury, which was more frequently observed in the SARS cases than in the non-SARS cases, no significant differences in terms of morphology and extent of alveolar damage were established. It is therefore of noticeable interest that SARS-related pathology lacks specific characteristics. It seems to be impossible to distinguish DAD caused by SARS from DAD caused by, for instance, trauma, aspiration, oxygen toxicity, or infectious microorganisms. Therefore, additional tests such as in situ hybridization, $I H C$, viral isolation, or RT-PCR are necessary to confirm the diagnosis.

Both sense and anti-sense probes with specificity for several viral proteins have been used for in situ hybridization. ${ }^{13,15,22-24,27-33}$ In situ hybridization has been performed on lung tissue of 67 SARS cases, of which 31 showed positive staining of epithelial cells. After doublelabeling with cytokeratin/anti-epithelial membrane antigen (Figure 1C) and surfactant protein A, these cells were identified as type II pneumocytes. ${ }^{15,22,24,27,28,30-33}$ Some studies also found positive in situ hybridization signals in epithelial cells of bronchi, bronchioles, trachea, and multinucleated cells. ${ }^{15,22,23,28,30}$ In addition, infection of alveolar macrophages ${ }^{15,22-24,27,28,33}$ and lymphocytes
(Figure 1D) ${ }^{15,33}$ has also been confirmed by double labeling. We found positive in situ hybridization signals in both fibroblasts and vascular endothelial cells (Figure 1D). ${ }^{33} \mathrm{Up}$ to 62 days after onset of disease, in situ hybridization has detected viral sequences in lung tissue. ${ }^{15}$ Three research groups have used immunofluorescence and fluorescence in situ hybridization with several cell markers and have found infected pneumocytes, bronchiolar epithelial cells, and macrophages. ${ }^{22,29,31}$

IHC with antibodies against SARS-CoV nucleocapsid $(\mathrm{N})$ protein, spike $(\mathrm{S})$ protein, and nonstructural protein 3a has been performed in 47 SARS cases. ${ }^{23,24,26,28-30}$ Positive staining of alveolar epithelial cells and macrophages was observed in 12 of 47 cases. ${ }^{24,26,28-30} \mathrm{Lim}$ ited staining of bronchiolar epithelium has also been reported. ${ }^{28}$ Positive IHC has not been established in cases with a disease duration exceeding 20 days. ${ }^{28,30}$

Specific immunohistochemical staining with antibodies to P-selectin, dendritic cell-specific ICAM3-grabbing nonintegrin (DC-SIGN), and interferon-inducible protein-10 (IP-10) has been performed in a number of cases. ${ }^{26,34,35}$ Increased expression of DC-SIGN, P-selectin, and IP-10 in both pneumocytes and macrophages was demonstrated. ${ }^{24,34,35}$ The results of immunostaining with antibodies directed against monocyte chemoattractant protein 1 , transforming growth factor- $\beta 1$, tumor necrosis factor- $\alpha$, interleukin-1, and interleukin-6 in SARS patients have recently been reported by $\mathrm{He}$ and colleagues $^{23}$ Strong expression of such proinflammatory cytokines was found in angiotensin-converting enzyme 2 (ACE2)positive cells infected with SARS-CoV. ${ }^{23}$

Ultrastructurally, SARS-CoV infection of cultured cells has shown features similar to those of previously described coronaviruses. ${ }^{36}$ SARS-specific characteristics include large granular cytoplasmic areas, nucleocapsid inclusions, and typical double-membrane vesicles. ${ }^{36}$ In some SARS autopsies, EM examination has revealed cytoplasmic viral particles in pneumocytes. ${ }^{12,14,22,24,28,30}$ The majority of these viral particles were within membrane-bound vesicles. Viral particles have also been observed in macrophages in lung tissue. ${ }^{22}$ In addition, the presence of viral inclusion bodies has been reported. ${ }^{24,30}$ In some studies the viral origin of the identified particles and inclusion bodies has been confirmed by immunogold labeling. ${ }^{15,24}$

SARS-CoV was successfully isolated from lung tissue in 10 of 23 cases, including cases with a duration of illness of up to 20 days. ${ }^{14,17,31}$ By RT-PCR, genomic sequences were found in the lungs of 47 of 55 SARS autopsies. ${ }^{16,18,22,28,30}$ Quantitative RT-PCR has detected viral sequences in lung tissues up to 51 days after onset of symptoms. ${ }^{37}$

Similar to SARS, avian influenza A (H5N1) is an emerging viral infectious disease that targets the lungs. Both diseases often result in respiratory distress, with a high fatality rate. Certain pathological similarities and differences between the two diseases have been described in a comparative review. ${ }^{38}$ DAD in H5N1 influenza cases shows a more fulminant progression, compared with that in SARS, with marked hemorrhage and necrosis. ${ }^{38}$ Multinucleated cells were readily noticeable in SARS 
cases, whereas the presence of such cells has thus far not been reported in $\mathrm{H} 5 \mathrm{~N} 1$ influenza cases. The organizing phase of H5N1 influenza seems to be characterized by paucicellular fibrosis, without the BOOP-like pattern as found in SARS autopsies. With respect to extrapulmonary manifestations, SARS is less often associated with a reactive hemophagocytic syndrome.

\section{Immune System}

In most SARS autopsies, both extensive necrosis of the spleen and atrophy of the white pulp with severe lymphocyte depletion have been found. ${ }^{11-14,17,27}$ Zhan and colleagues $^{27}$ have demonstrated a sharp decrease in the number of periarterial sheaths in the spleen (Figure 1E). ${ }^{27}$ Quantification of the various immune cells residing in the spleen including $\mathrm{CD}^{+}$lymphocytes, $\mathrm{CD}^{+}$lymphocytes, $\mathrm{CD}_{20} \mathrm{O}^{+}$lymphocytes, dendritic cells, macrophages, and natural killer cells showed a decrease of 78 , $83,90,80,39$, and 48\%, respectively. The average size of macrophages was found to be increased by more than $100 \% .{ }^{27}$ Some studies have failed to detect any positive viral signal in splenic cells ${ }^{30-32}$ or to isolate virus from cultures of splenic tissue..$^{11,14,31}$ In contrast, others have detected infection of $\mathrm{T}$ Iymphocytes and macrophages in the spleen ${ }^{15,27}$ and reported high viral loads in this organ. ${ }^{37}$

Lymph nodes usually show atrophy and reduction of lymphocytes with loss of germinal centers. ${ }^{12,13,15,17}$ Focal necrotic inflammation of hilar lymph nodes has been found in some cases. ${ }^{13}$ Evidence of hemophagocytosis in lymph nodes was observed in a limited number of cases. ${ }^{17,38}$ High viral loads have been detected in lymph nodes, whereas viral isolation was negative. ${ }^{11,31,37}$ Both in situ hybridization and EM have confirmed SARS-CoV infection of immune cells residing in lymph nodes, and by double labeling these cells were identified as macrophages and T lymphocytes. ${ }^{15}$

In several cases, severe depletion of mucosal lymphoid tissue in the small intestines and appendix has been described. Decrease of lymphocytes, depletion of follicles, and loss of germinal centers were noted. ${ }^{39}$ EM and in situ hybridization have, respectively, revealed viral particles and genetic sequences in the remaining lymphocytes. ${ }^{15,39}$

EM has also detected viral particles in circulating monocytes and $\mathrm{T}$ lymphocytes and to a lesser extent in natural killer cells and B lymphocytes found in blood samples collected in the early phase of the disease. ${ }^{15}$ In several SARS autopsies, infection of T lymphocytes and monocytes within blood vessels were confirmed by in situ hybridization and EM. ${ }^{15}$

\section{The Central Nervous System}

Several observations suggest that SARS-CoV is capable of causing an infection of the central nervous system. RT-PCR has detected SARS-CoV genomic sequences in cerebral spinal fluid and in brain tissue specimens (Figure 1F). ${ }^{40-42}$ The virus has been successfully isolated from brain tissue. ${ }^{42}$ Edema and focal degeneration of neurons have been observed in the brains of SARS autopsies. ${ }^{13,15} \mathrm{IHC}$, in situ hybridization, and EM have confirmed viral infection of neurons. ${ }^{13,15,42}$ Gliocytes have also been found infected by SARS-CoV. ${ }^{42}$

\section{The Urogenital Tract}

Kidneys of autopsied SARS patients have shown focal necrosis and vasculitis of small veins in the renal interstitial tissue. ${ }^{12}$ In addition, monocytic infiltration, acute tubular necrosis, and other nonspecific changes, such as glomerular fibrosis and nephrosclerosis, have all been observed. ${ }^{12,13,17,43,44}$ Quantitative RT-PCR has detected high viral loads in the renal tissue specimens of several SARS patients. ${ }^{37}$ In situ hybridization and IHC have identified viral genomic sequences and proteins, respectively, in the epithelial cells of the distal tubules. ${ }^{15,23,30}$ Viral particles have been localized to the cytoplasm of these cells through EM. ${ }^{15}$ These findings may explain the presence of SARS-CoV sequences in urinary samples of SARS patients. 6,7

The testes of seven of seven male SARS patients displayed germ cell destruction, showing few or no spermatozoa in the seminiferous epithelium or lumen and a mixed cellular infiltrate. Significantly increased numbers of apoptotic spermatogenetic cells were identified. ${ }^{45}$ In situ hybridization and EM have failed to demonstrate SARS viral sequences and viral particles in the testes. ${ }^{15,30,45}$

\section{Gastrointestinal Tract}

Gastrointestinal manifestations are commonly reported in SARS cases, with more than $20 \%$ of the patients presenting with watery diarrhea and up to $67 \%$ of patients developing diarrhea during the course of the illness. ${ }^{6,8,46}$ Microscopic examination has not detected any evident pathological changes, other than nonspecific changes in tissue specimens of small and large intestines, such as autolysis and mild focal inflammation. ${ }^{13,14,39,46}$ The most evident pathological finding was depletion of the mucosal lymphoid tissue in the pharynx, appendix, and small intestines, as described above. The pancreas, stomach, and salivary glands have not shown any obvious pathological changes. ${ }^{39,46}$ Positive in situ hybridization signals have been observed in the cytoplasm of mucosal epithelial cells, ${ }^{15,23,29-31,39}$ as well as in mucosal and submucosal lymphocytes. ${ }^{39}$ Viral particles were identified by EM in the mucosal epithelial cells and were localized to the dilated endoplasmic reticulum and the surface of the microvilli. 29,39,46 Viral sequences were not detected in the esophagus. ${ }^{39}$ Viral proteins and genomic sequences have been observed in gastric parietal cells but not in gastric chief cells. ${ }^{23}$ RT-PCR and viral isolation were positive on intestinal tissue specimens. ${ }^{14,46,31,32}$ Infection of the intestinal tract may provide an explanation for the detection of viral RNA in stool samples. ${ }^{6,7}$ Nevertheless, SARS-CoV could not readily be isolated from stool samples. ${ }^{7}$ 


\section{Liver}

The majority of SARS patients showed a transient increase in serum alanine aminotransferase levels during the course of their disease. ${ }^{47}$ High peak alanine aminotransferase levels have been associated with an adverse outcome. ${ }^{47}$ In some autopsy cases fatty degeneration, necrosis of hepatocytes, and cellular infiltration were observed, ${ }^{12,13,17,39}$ whereas in other cases no specific pathological changes have been described. ${ }^{9}$ RT-PCR was positive on liver tissue in several cases. ${ }^{9,37,48}$ However, in situ hybridization and EM failed to detect either viral genomic sequences or particles in most cases. $^{31,32,39,48}$ Liver tissues obtained through percutaneous biopsies showed mitotic hepatocytes with evidence of apoptosis. ${ }^{48}$

\section{Bone Marrow}

In some cases, evidence of reactive hemophagocytosis or bone marrow hypoplasia was present. ${ }^{13,25,38}$ In other cases, however, active bone marrow without reactive hemophagocytosis has been demonstrated. ${ }^{11}$ In situ hybridization and $\mathrm{IHC}$ have detected neither viral genomic sequences nor antigens. ${ }^{30,31}$ Both viral isolation and RTPCR performed on bone marrow were negative. ${ }^{11,25,31}$

\section{Thyroid Gland}

Destruction of epithelial cells with significant changes in the follicular architecture was present in the thyroid glands of five of five SARS autopsies. No distinct calcitonin-positive cells were identified. Cellular infiltration was not observed. ${ }^{49}$ Fibrosis in the interfollicular connective tissue has been described in one case. Terminal deoxynucleotidyl transferase-mediated dUTP nick-end labeling assay has demonstrated several apoptotic cells. ${ }^{49}$ In contrast, however, in situ hybridization has not detected any viral sequences in thyroid tissues ${ }^{15,31}$ except in leukocytes within blood vessels distributed in the organ. ${ }^{15}$ Acidophilic cells of the parathyroid gland showed positive in situ hybridization signals. ${ }^{23,30}$

\section{Skeletal Muscle}

Both myofiber necrosis and atrophy were observed in the limited number of skeletal muscle tissue specimens of SARS autopsies examined in this respect. ${ }^{50}$ Such necrosis was characterized as coagulative and karyorrhexic, with cellular debris in some cells. ${ }^{50}$ Regenerative myofibers and infiltrating macrophages were scarce. These changes may possibly be ascribed to a combination of the use of corticosteroids during treatment, critical illness neuropathy, and SARS-CoV-related myopathy. ${ }^{50}$ Edema of the walls of small veins and arteries has also been reported. ${ }^{12}$ In situ hybridization and EM examinations have not detected any viral genetic sequences or particles. $^{30,32,50}$ Although RT-PCR on skeletal muscle tissue was positive in a few cases, SARS-CoV could not be isolated from skeletal muscle tissue. ${ }^{37,50}$

\section{Other Organs}

The few available studies on adrenal glands described the presence of necrosis and vasculitis of the medulla with monocytic and lymphocytic infiltration. ${ }^{12,13}$ Viral antigens and genomic sequences have been identified in adrenal glands. ${ }^{23,30}$ Edema of both myocardial stroma, as well as vascular walls, and atrophy of cardiac muscle fibers have all been demonstrated. ${ }^{12,13}$ In addition, in one SARS autopsy vegetations on the mitral, tricuspid, and aortic valve were observed. ${ }^{17}$ Viral isolation, in situ hybridization, and $\mathrm{IHC}$ were negative in most cases, whereas RT-PCR on cardiac tissue was positive in some cases. ${ }^{14,17,30-32,37}$ SARS-CoV genomic sequences and antigens have also been detected in sweat glands and pancreatic islet cells. ${ }^{23,30}$ Because SARS-CoV genomic sequences may be carried by immune cells circulating in a particular organ, positive RT-PCR results do not imply that the parenchymal cells of that organ are also infected.

\section{Pathogenesis}

Although reports describing cell and organ pathology and viral distribution have contributed to a better understanding of the pathogenesis of SARS, research regarding receptor interaction, immune system response, and genetic factors will provide additional insights. Below, we summarize the important discoveries in these regards and the major etiological mechanisms are discussed. Figure 2 contains a schematic representation of these mechanisms.

\section{ACE2 and Other SARS-CoV Receptors}

ACE2, a metallopeptidase, was identified as the functional receptor for SARS-CoV. ${ }^{51}$ Subsequent studies have described the tissue distribution of ACE2 through immunohistochemical staining. ${ }^{23,52,53}$ With respect to the respiratory tract, ex vivo experiments have detected ACE2 on the luminal surface of tracheobronchial and alveolar epithelium. ${ }^{52,54}$ In general, the receptor distribution pattern resembles that of infected organs and cells as demonstrated by in situ hybridization and RT-PCR. However, the abundant expression of ACE2 in endothelial cells and smooth muscle cells of several visceral organs is discordant with the absence of the virus in these organs. ${ }^{53}$ In addition, only one of seven ACE2expressing intestinal cell lines seemed to be susceptible to SARS-CoV infection in vitro. ${ }^{55}$ At the same time, however, the lack of ACE2 expression in immune cells, coIonic epithelial cells, and in neuronal cells of the brain contrasts with the confirmed infection of such cells. These contradictions suggest that other receptors, coreceptors, or mechanisms may be involved in the interaction between the virus and its target cells. ${ }^{15,53} \mathrm{Re}$ cently, human autopsy studies have shown that SARSCoV S protein and its RNA could be detected in ACE2positive cells and not in ACE2-negative cells, implying that only ACE2-positive cells are susceptible to SARSCoV infection. ${ }^{23}$ However, this contradicts the above re- 

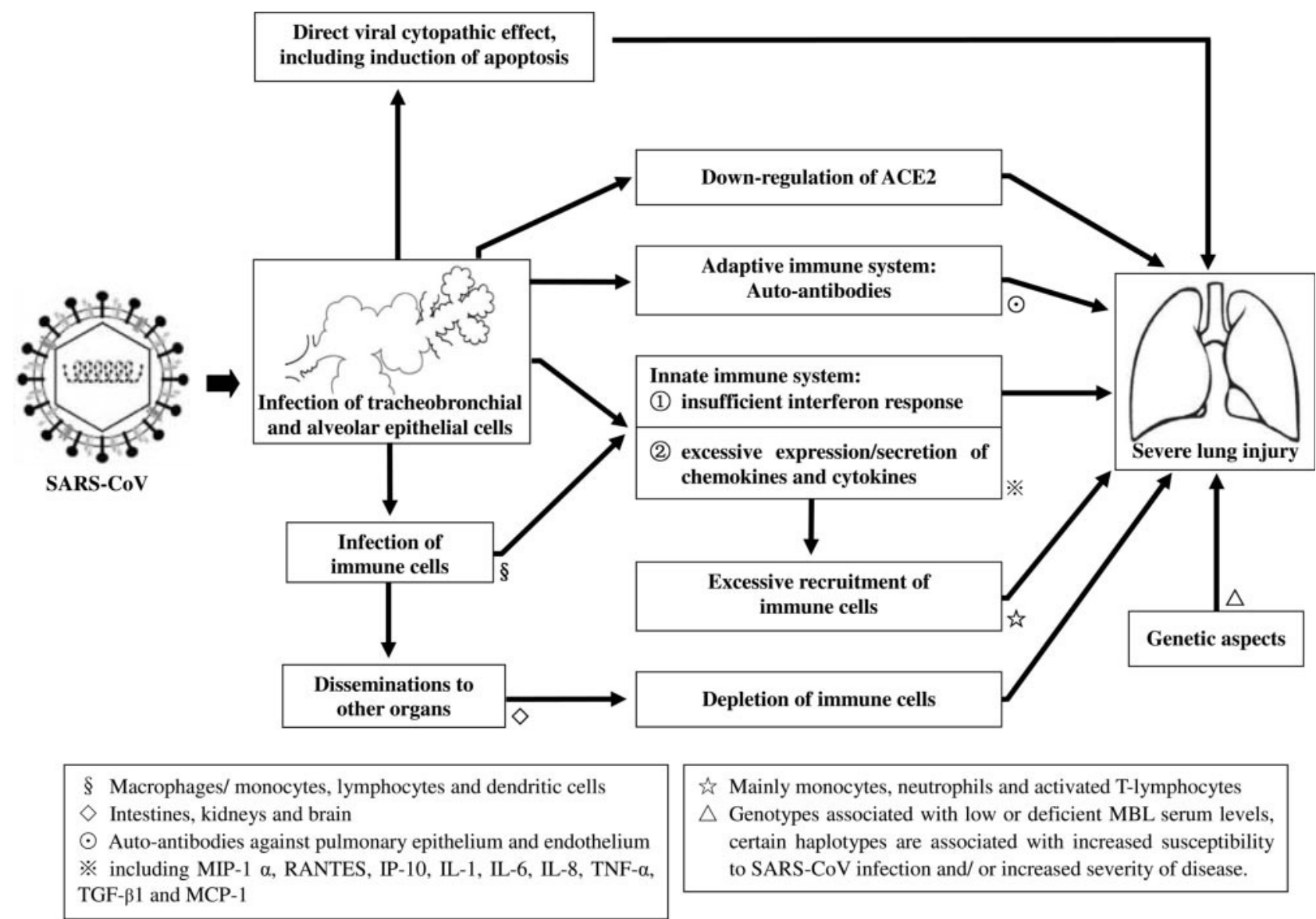

is Mainly monocytes, neutrophils and activated T-lymphocytes

$\triangle$ Genotypes associated with low or deficient MBL serum levels, certain haplotypes are associated with increased susceptibility to SARS-CoV infection and/ or increased severity of disease.

Figure 2. Major mechanisms contributing to the pathogenesis of SARS. These pathological events and cascade of changes form the basis for clinical symptoms and pathological findings at different stages of SARS. Correct understanding of the pathogenesis will provide guidance to prevention, diagnosis, and treatment of this new disease. MIP- $1 \alpha$, macrophage inflammatory protein- $1 \alpha$; RANTES, regulated on activation normal T cell expressed and secreted; TNF- $\alpha$, tumor necrosis factor- $\alpha$; TGF- $\beta 1$, transforming growth factor- $\beta 1$; MCP- 1 , monocyte chemoattractant protein- 1 .

ports of the presence of SARS-CoV sequence in ACE2negative cell types. Further investigations are called for to address this controversy.

At the molecular level, SARS-CoV enters the apical surface of well-differentiated epithelium of the respiratory tract, where ACE2 is expressed more abundantly than basolaterally. ${ }^{51,56}$ The apical surface also seems to be the preferential site of viral exit. ${ }^{56}$ SARS-CoV infection of ACE2-expressing cells seems to be dependent on the proteolytic enzyme cathepsin $L .{ }^{57,58}$ Cathepsin $L$ is poorly expressed in endothelial cells which may explain the low infection rate of these cells despite the high expression of ACE2. ${ }^{57}$ SARS-CoV infection seems to be $\mathrm{pH}$-dependent because the activation of cathepsin $\mathrm{L}$ is $\mathrm{pH}$ sensitive. ${ }^{58}$ Differential expression of cathepsin $\mathrm{L}$ in various cell types may explain the differences in viral distribution in relation to the ACE2 expression pattern.

Liver/lymph node-specific ICAM3-grabbing nonintegrin (L-SIGN) and dendritic-cell-specific DC-SIGN have both been identified as alternative SARS-CoV receptors. ${ }^{59,60}$ L-SIGN expression is generally found in lymph nodes and liver sinusoidal cells. ${ }^{61}$ By $\mathrm{IHC}$ it has been demonstrated that L-SIGN is also expressed on type ॥ pneumocytes and endothelial cells. ${ }^{59}$ In general, DCSIGN is mainly expressed in certain types of dendritic cells and alveolar macrophages. ${ }^{62}$ However, in the lung tissue of SARS autopsies, DC-SIGN has also been localized to pneumocytes, which may indicate that SARS infection is capable of inducing DC-SIGN expression. ${ }^{26}$ In vitro experiments have demonstrated that cells expressing DC-SIGN or L-SIGN without ACE-2 are not, or are only partially, susceptible to SARS-CoV infection. ${ }^{59,60,63}$ This would imply that these molecules are much less efficient receptors than ACE2 as specific receptors and may therefore merely enhance infection of permissive cells. ${ }^{60,63}$ Dendritic cells expressing DC-SIGN may transfer SARS-CoV to susceptible cells such as pneumocytes through a synapse-like structure. ${ }^{63}$

Not only does ACE2 function as a SARS-CoV receptor, it also plays an essential role in the pathogenesis of SARS. ACE2 is a key molecule in the renin-angiotensin system. It counteracts the effects of ACE on the reninangiotensin system and down-regulates the production of angiotensin II. ${ }^{64} \mathrm{ACE} 2$ and AT2-receptors play protective roles in severe acute lung injury, whereas ACE, angiotensin II, and AT1-receptors probably induce lung failure. ${ }^{64}$ Animal experiments have demonstrated that binding of SARS-COV S protein to ACE2 down-regulates the expression of ACE2, resulting in a diminished protective role of ACE2 and, subsequently, acute respiratory 
failure. ${ }^{65}$ Likewise, the SARS-CoV-mediated down-regulation of ACE2 in humans provides an explanation for the progression to severe lung injury in some SARS patients.

\section{Viral Cytopathic Effects}

Direct viral effects are also likely to contribute to the serious pulmonary injury resulting from SARS-CoV infection. In particular, during the first 10 days of the disease when virus replication is prevalent, viral effects seem to play an important role. The virus is capable of causing cytopathic effects in both Vero E6 cells and ciliated tracheobronchial epithelial cells in vitro., ${ }^{1,52}$ The presence of multinucleated cells in SARS lungs may also be the result of viral cytopathic effects (Figure 1B). ${ }^{23}$ Induction of apoptosis in SARS-CoV-infected Vero E6 cells has been confirmed by morphological and biochemical analyses. ${ }^{66}$ SARS-CoV nonstructural proteins may be involved in this process. ${ }^{67,68}$ Furthermore, SARS-CoV structural proteins also have the ability to trigger apoptosis in vitro. ${ }^{69}$ Overexpression of SARS-CoV 7 a induces apoptosis through a caspase-dependent pathway in several human cell lines, including cells derived from the liver, kidneys, and lungs. ${ }^{67}$ SARS-CoV E proteins may be involved in T-cell apoptosis through inhibition of anti-apoptotic proteins $\mathrm{BCl}-\mathrm{XL} .{ }^{69}$ In vivo studies have reported evidence of apoptosis in cells of thyroid glands, spermatogenetic cells, epithelial cells, pneumocytes, monocytes/ macrophages, lymphocytes, and hepatocytes. 23,45,48,49 As mentioned above, increased expression of transforming growth factor- $\beta 1$ has been detected in infected alveolar and bronchial epithelial cells. ${ }^{23}$ Because transforming growth factor- $\beta 1$ is an enhancer of Fas-mediated cell apoptosis, strong induction of this cytokine may also partially account for apoptosis of such cells. ${ }^{23}$

\section{Infection of Immune Cells}

In vitro infected peripheral blood mononuclear cells (PBMCs) have shown viral replication up to 8 days. ${ }^{70}$ In other experiments, however, SARS-CoV infection of macrophages, monocytes, and dendritic cells seemed to be abortive. ${ }^{71,72}$ In PBMCs obtained from SARS patients, SARS-CoV has also been found to infect and replicate, although replication was self-limiting ${ }^{73}$ We have confirmed infection of various circulating immune cells including monocytes and T lymphocytes in the early phase of the disease. ${ }^{15}$ Mean infection rates of lymphocytes and monocytes amounted to 51.5 and $29.7 \%$, respectively. Furthermore, we have provided evidence of infection of both $T$ lymphocytes (Figure 1D) and macrophages/monocytes in the circulating blood, lymph nodes, lungs, and spleens in SARS autopsies. ${ }^{15,27,33}$ These findings may provide a partial explanation for the lymphopenia and the widespread destruction of spleen and lymphoid tissue in the majority of SARS patients. However, considering the relatively long half-life of circulating lymphocytes, other factors, such as aberrant homing of lymphocytes, apoptosis, autophagy, and infection of bone marrow precursor cells may also contribute to the severe reduction of lymphocytes. As for SARS, the role of these factors has not yet been clarified. Infected immune cells may cause widespread dissemination to various organs, as has been reported in some studies. ${ }^{15,27,30,49}$ Because monocytes and T cells are involved in both the innate and adaptive immune system, the destruction of such cells may result in a compromised immune response. In our view, this may contribute to the occurrence of severe pulmonary injury. ${ }^{15}$ This is supported by observations that low CD4 and CD8 T-lymphocyte counts correlate with disease severity and adverse outcome. ${ }^{10,11}$ Lymphopenia is frequently observed in other viral infectious viral diseases, such as measles, Ebola, Lassa fever, and respiratory syncytial virus infections. ${ }^{74-76}$ However, in these diseases, direct infection and subsequent destruction of lymphocytes are generally regarded unlikely to account for the severe lymphocyte depletion. In measles, for instance, only a small proportion of the patient's PBMCs are infected during acute infection, ${ }^{74}$ contrasting with the high infection rates of PBMCs in SARS. In respiratory syncytial virus infections, macrophages/monocytes are the primary immune cells targeted by the virus, ${ }^{76}$ whereas viruses causing hemorrhagic fever are not capable of infecting lymphocytes. ${ }^{76}$

\section{Chemokines and Cytokines}

Both cytokines and chemokines (chemotactic cytokines) are soluble proteins with a key function in the innate immune system. Dysregulation of these proteins may result in immune-mediated injury. In the early reports after the emergence of SARS, it had already been suggested that the severe SARS-related injury may be attributable to an excessive reaction of the host's immune system, particularly dysregulation of proinflammatory cytokines. ${ }^{16}$ This assumption is supported by the clinical deterioration of many patients in the second week of the disease's course, despite decreasing viral loads. ${ }^{6,16}$ Increased serum levels of several cytokines were found in the majority of the SARS patients. ${ }^{60,65}$ However, no consistent cytokine profile has been reported to date. Later reports have failed to demonstrate significant increases of serum levels of cytokines that normally play an important role in the immune defense against viruses. ${ }^{34,77}$ In contrast, an increase of immunosuppressive soluble factors prostaglandin E2 and transforming growth factor $\beta$ in serum was detected in certain cases, providing an alternative explanation for the prolonged and severe clinical course. $^{53}$

Recent studies have focused on the role of chemokines rather than cytokines in SARS infection. High serum levels of various types of chemokines were detected in several SARS patients. ${ }^{34,35,78,79}$ In vitro experiments have demonstrated that SARS-CoV infection of macrophages, dendritic cells, and alveolar epithelial cells induces significant gene overexpression of chemokines, including macrophage inflammatory protein- $1 \alpha$, regulated on activation normal $\mathrm{T}$ cell expressed and secreted, IP-10, interleukin-8, and monocyte chemoattractant protein-1. ${ }^{26,71,72}$ Increased secretion of these 
chemokines has been confirmed in culture supernatants of infected cells. ${ }^{26,72}$ In addition, expression of the IP-10 gene seemed to be significantly increased in lung tissue and lymphoid tissue of autopsied SARS patients, which was also confirmed by IHC with anti-IP-10 antibodies. ${ }^{34,35}$ Increased IP-10 concentration has been found to be an independent predictor of adverse outcome. ${ }^{35} \mathrm{He}$ and colleagues ${ }^{23}$ have recently demonstrated strong induction of several proinflammatory cytokines and chemokines in cells expressing both ACE2 and SARS-CoV S protein in SARS patients, which may imply that up-regulation of such cytokines in virus-infected cells may contribute to acute lung injury. ${ }^{23}$

Based on the results of the above-mentioned in vitro and in vivo experiments, SARS-CoV infection of pneumocytic epithelial cells may theoretically induce secretion of chemokines in vivo, mediating migration of monocytes and neutrophils to the infection site. ${ }^{26}$ Infection of dendritic cells and recruited macrophages may subsequently result in secretion of additional chemokines, thus further enhancing migration of several types of immune cells, including activated T cells. ${ }^{26,71,72}$ Excessive induction of proinflammatory cytokines and chemokines and recruitment of immune cells together possibly explain the severity of the injury often observed in the lungs of SARS patients.

\section{The Innate Immune Response}

Recent studies have investigated the role of the innate immune response in the pathogenesis of SARS. The fact that the virus replicates progressively in the upper respiratory tract during the first 10 days of the disease has raised the suggestion that SARS infection may cause deficiencies in the innate immune response. . $71,72^{\text {The }}$ innate immune system constitutes the first line of the immune defense against viruses and involves several cellular components and soluble factors. ${ }^{56}$ With respect to the role of the innate immune system in SARS-CoV infection, interferons, mannose-binding lectin (MBL), macrophages, and dendritic cells have all been studied. In viral infections in general, interferons are produced and secreted by infected cells. These cells cause adjacent cells to synthesize antiviral agents that tend to restrict viral dissemination. Contrary to other viruses, SARS$\mathrm{CoV}$ is not capable of inducing significant interferon- $\alpha$ or $-\beta$ gene expression in infected macrophages, PBMCs, or infected dendritic cells. ${ }^{71,72}$ SARS-CoV may evade the effects of interferon induction by blocking a specific molecular step in the activation of interferon- $\beta^{8}{ }^{80}$ In addition, SARS-CoV seems to impair the phagocytic capacity of macrophages, which may render SARS patients prone to secondary pulmonary infections. ${ }^{81}$ SARS-CoV also causes phenotypic and functional maturation of dendritic cells in vitro, resulting in a moderate production of cytokines and an enhanced T-cell-stimulatory capacity. ${ }^{81} \mathrm{Ac}-$ tivated T cells may exert cytotoxic activity in the lungs, further contributing to pulmonary injury.

$M B L$ deficiency seems to play a key role in the pathogenesis of SARS. MBL is a serum protein that can bind to the ligands of various pathogens, flagging them for immune destruction, independently of a specific antibody response. ${ }^{82} \mathrm{MBL}$ is capable of binding to SARS-CoV and inhibiting SARS-CoV infectivity in vitro. ${ }^{83}$ Both low MBL serum levels and haplotypes associated with MBL deficiency have been detected in SARS patients. ${ }^{83}$

\section{Autoimmunity}

Autoimmunity may also be involved in the pathogenesis of SARS. Autoantibodies against pulmonary epithelial cells and endothelial cells have been detected in SARS patients. ${ }^{84,85}$ These autoantibodies may cause cytotoxic injury to the pulmonary epithelial cells and may induce systemic vasculitis, both frequently observed in SARS autopsies ${ }^{84,85}$ Autoimmunity may be partially attributable to the development of cross-reacting antibodies against specific SARS-CoV epitopes. IgG antibodies against the domain 2 of spike protein have indeed been found to cross-react with pulmonary epithelial cells. ${ }^{84}$ Another mechanism that possibly explains autoimmunity is the exposure of autoantigens caused by cytokine-induced organ injury. ${ }^{85}$

\section{Host Factors}

Certain host factors have been found to affect the course of disease and outcome of SARS, including age, sex, and pre-existing co-morbid conditions. ${ }^{8,86-90}$ Advanced age is independently associated with higher mortality, ${ }^{8,86}$ as evidenced by fatality rates ranging from $3 \%$ in the youngest age group to $55 \%$ in the oldest age group. ${ }^{86}$ Survival is also associated with sex, with male cases showing a significantly higher mortality than female cases. ${ }^{86,87} \mathrm{~Pa}$ tients with co-morbid conditions such as diabetes mellitus, cardiac diseases, pulmonary diseases, and chronic hepatitis furthermore showed a significant increase of mortality. ${ }^{86-90}$ In an analysis of 1755 patients, the case fatality rate for patients with co-morbid conditions amounted to $46 \%$, compared with $10 \%$ for those without co-morbid conditions. ${ }^{86}$ The fact that these co-morbidities are all characterized by a decreased cardiopulmonary status and/or a compromised immune system ${ }^{88,89}$ possibly accounts for the increased mortality. Use of glucocorticoids, a key component of SARS treatment, may further aggravate the pre-existing illness, resulting in an even worse outcome. ${ }^{88}$

\section{Genetics}

Genetic factors also seem to play a causative role in the pathogenesis of SARS. For a group of Taiwanese patients, the HLA-B*4601 haplotype was associated with severity of SARS infection. ${ }^{91}$ This association has not been established for certain Hong Kong Chinese patients. ${ }^{92}$ Nevertheless, in the latter group of patients, a strong association was demonstrated between HLA$B^{*} 0703$ and HLA-DRB1 ${ }^{*} 0301$ alleles and an increased susceptibility to SARS infection. ${ }^{92}$ In contrast, L-SIGN homozygote individuals seem to have a significantly 
lower risk of SARS infection. ${ }^{93}$ Furthermore, genotypes associated with low or deficient MBL serum levels have more frequently been detected in SARS patients than in control cases. ${ }^{83}$

\section{Concluding Remarks}

In conclusion, extensive reports about the pathology and pathogenesis of SARS present a complex picture of the etiological factors involved, the intricate causes and consequences and their interplay. It is noteworthy that although the major clinical manifestations of the disease involve the respiratory system, the key component of the pathogenesis seems to be related to the immune system. Hyperinduction of chemokines and cytokines, insufficient interferon reaction, and a compromised cellular immune response caused by direct infection or indirect injury of immune cells may all contribute to SARS-related pathological changes. ${ }^{94} \mathrm{~A}$ compromised immune response may lead to aggravation of SARS-CoV-induced lung injury, which otherwise might not have been so widespread and devastating. A more comprehensive understanding of the key features of the pathogenesis is crucial to establish appropriate animal models, which are essential for the production of vaccines. Advances made in the fields of pathology and pathogenesis of SARS will also serve to guide the diagnosis, prevention, and treatment of SARS should it or a similar disease appear in the future.

\section{References}

1. Drosten C, Gunther S, Preiser W, van der Werf S, Brodt HR, Becker S, Rabenau H, Panning M, Kolesnikova L, Fouchier RA, Berger A, Burguiere AM, Cinatl J, Eickmann M, Escriou N, Grywna K, Kramme S, Manuguerra JC, Muller S, Rickerts V, Sturmer M, Vieth S, Klenk HD, Osterhaus AD, Schmitz H, Doerr HW: Identification of a novel coronavirus in patients with severe acute respiratory syndrome. N Engl J Med 2003, 348:1967-1976

2. Fouchier RA, Kuiken $T$, Schutten $M$, van Amerongen $G$, van Doornum GJ, van den Hoogen BG, Peiris M, Lim W, Stohr K, Osterhaus AD: Aetiology: Koch's postulates fulfilled for SARS virus. Nature 2003, 423:240

3. Marra MA, Jones SJ, Astell CR, Holt RA, Brooks-Wilson A, Butterfield YS, Khattra J, Asano JK, Barber SA, Chan SY, Cloutier A, Coughlin SM, Freeman D, Girn N, Griffith OL, Leach SR, Mayo M, McDonald H, Montgomery SB, Pandoh PK, Petrescu AS, Robertson AG, Schein JE, Siddiqui A, Smailus DE, Stott JM, Yang GS, Plummer F, Andonov A, Artsob H, Bastien N, Bernard K, Booth TF, Bowness D, Czub M, Drebot M, Fernando L, Flick R, Garbutt M, Gray M, Grolla A, Jones S, Feldmann H, Meyers A, Kabani A, Li Y, Normand S, Stroher U, Tipples GA, Tyler S, Vogrig R, Ward D, Watson B, Brunham RC, Krajden M, Petric M, Skowronski DM, Upton C, Roper RL: The genome sequence of the SARS-associated coronavirus. Science 2003, 300:1399-1404

4. Guan $Y$, Zheng BJ, He YQ, Liu XL, Zhuang ZX, Cheung CL, Luo SW, Li PH, Zhang LJ, Guan YJ, Butt KM, Wong KL, Chan KW, Lim W, Shortridge KF, Yuen KY, Peiris JS, Poon LL: Isolation and characterization of viruses related to the SARS coronavirus from animals in southern China. Science 2003, 302:276-278

5. Li W, Shi Z, Yu M, Ren W, Smith C, Epstein JH, Wang H, Crameri G, Hu Z, Zhang H, Zhang J, McEachern J, Field H, Daszak P, Eaton BT, Zhang S, Wang LF: Bats are natural reservoirs of SARS-like coronavirus. Science 2005, 310:676-679

6. Peiris JS, Yuen KY, Osterhaus AD, Stohr K: The severe acute respiratory syndrome. N Engl J Med 2003, 349:2431-2441
7. Chan KH, Poon LL, Cheng VC, Guan Y, Hung IF, Kong J, Yam LY, Seto WH, Yuen KY, Peiris JS: Detection of SARS coronavirus in patients with suspected SARS. Emerg Infect Dis 2004, 10:294-299

8. Donnelly CA, Chani AC, Leung GM, Hedley AJ, Fraser C, Riley S, Abu-Raddad LJ, Ho LM, Thach TQ, Chau P, Chan KP, Lam TH, Tse LY, Tsang T, Liu SH, Kong JH, Lau EM, Ferguson NM, Anderson RM: Epidemiological determinants of spread of causal agent of severe acute respiratory syndrome in Hong Kong. Lancet 2003, 361:1761-1766

9. Chan HLY, Leung WK, To KF, Chan PKS, Lee N, Wu A, Tam JSL, Sung JJY: Retrospective analysis of liver function derangement in severe acute respiratory syndrome. Am J Med 2004, 116:566-567

10. He Z, Zhao C, Dong Q, Zhuang H, Song S, Peng G, Dwyer DE: Effects of severe acute respiratory syndrome (SARS) coronavirus infection on peripheral blood lymphocytes and their subsets. Int J Infect Dis 2005, 9:323-330

11. Wong RSM, Wu A, To KF, Lee N, Lam CWK, Wong CK, Chan PKS, Margaret HLN, Yu LM, Hui DS, Tam JS, Cheng G, Sung JJY: Haematological manifestations in patients with severe acute respiratory syndrome: retrospective analysis. BMJ 2003, 326:1358-1362

12. Ding YQ, Wang HJ, Shen H, Li ZG, Geng J, Han HX, Cai JJ, Li X, Kang W, Weng DS, Lu YD, Wu DH, He L, Yao KT: The clinical pathology of severe acute respiratory syndrome (SARS): a report from China. J Pathol 2003, 200:282-289

13. Lang ZW, Zhang LJ, Zhang SJ, Meng X, Li JQ, Song CZ, Sun L, Zhou YS, Dwyer DE: A clinicopathological study of three cases of severe acute respiratory syndrome (SARS). Pathology 2003, 35:526-531

14. Tse GMK, To KF, Chan PKS, Lo AWI, Ng KC, Wu A, Lee N, Wong HC, Mak SM, Chan KF, Hui DSC, Sung JJY, Ng HK: Pulmonary pathological features in coronavirus associated severe acute respiratory syndrome (SARS). J Clin Pathol 2004, 57:260-265

15. Gu J, Gong EC, Zhang B, Zheng J, Gao ZF, Zhong YF, Zou WZ, Zhan $J$, Wang SL, Xie ZG, Zhuang H, Wu BQ, Zhong HH, Shao HQ, Fang WG, Gao DX, Pei F, Li XW, He ZP, Xu DZ, Shi XY, Anderson VM, Leong ASY: Multiple organ infection and the pathogenesis of SARS. $J$ Exp Med 2005, 202:415-424

16. Nicholls JM, Poon LL, Lee KC, Ng WF, Lai ST, Leung CY, Chu CM, Hui PK, Mak KL, Lim W, Yan KW, Chan KH, Tsang NC, Guan Y, Yuen KY, Peiris JS: Lung pathology of fatal severe acute respiratory syndrome. Lancet 2003, 361:1773-1778

17. Chong PY, Chui $P$, Ling AE, Franks TJ, Tai DY, Leo YS, Kaw GJ, Wansaicheong G, Chan KP, Ean Oon LL, Teo ES, Tan KB, Nakajima N, Sata T, Travis WD: Analysis of deaths during the severe acute respiratory syndrome (SARS) epidemic in Singapore: challenges in determining a SARS diagnosis. Arch Pathol Lab Med 2004, 128:195-204

18. Cheung OY, Chan JW, Ng CK, Koo CK: The spectrum of pathological changes in severe acute respiratory syndrome (SARS). Histopathology 2004, 45:119-124

19. Hwang DM, Chamberlain DW, Poutanen SM, Low DE, Asa SL, Butany $\mathrm{J}$ : Pulmonary pathology of severe acute respiratory syndrome in Toronto. Mod Pathol 2005, 18:1-10

20. Franks TJ, Chong PY, Chui P, Galvin JR, Lourens RM, Reid AH, Selbs E, McEvoy CPL, Hayden CDL, Fukuoka J, Taubenberger JK, Travis WD: Lung pathology of severe acute respiratory syndrome (SARS): a study of 8 autopsy cases from Singapore. Hum Pathol 2003, $34: 743-748$

21. Hsiao CH, Wu MZ, Chen CL, Hsueh PR, Hsieh SW, Yang PC, Su IJ: Evolution of pulmonary pathology in severe acute respiratory syndrome. J Formos Med Assoc 2005, 104:75-81

22. Nakajima N, Asahi-Ozaki Y, Nagata N, Yko S, Dizon F, Paladin FJ, Olveda RM, Odagiri T, Masato T, Sata T: SARS coronavirus-infected cells in lung detected by new in situ hybridization technique. Jpn $J$ Infect Dis 2003, 56:139-141

23. He L, Ding Y, Zhang Q, Che X, He Y, Shen H, Wang H, Li Z, Zhao L, Geng J, Deng Y, Yang L, Li J, Cai J, Qiu L, Wen K, Xu X, Jiang S: Expression of elevated levels of pro-inflammatory cytokines in SARSCoV-infected ACE2 $(+)$ cells in SARS patients: relation to the acute lung injury and pathogenesis of SARS. J Pathol 2006, 210:288-297

24. Shieh WJ, Hsiao CH, Paddock CD, Guarner J, Goldsmith CS, Tatti K, Packard M, Mueller L, Wu MZ, Rollin P, Su IJ, Zaki SR: Immunohistochemical, in situ hybridization, and ultrastructural localization of SARS-associated coronavirus in lung of a fatal case of severe acute respiratory syndrome in Taiwan. Hum Pathol 2005, 36:203-209 
25. Hsueh PR, Chen PJ, Hsiao CH, Yeh SH, Cheng WC, Wang JL, Chiang BL, Chang SC, Chang FY, Wong WW, Kao CL, Yang PC; SARS Research Group of National Taiwan University College of Medicine and National Taiwan University Hospital: Patient data, early SARS epidemic, Taiwan. Emerg Infect Dis 2004, 10:489-493

26. Yen YT, Liao F, Hsiao CH, Kao CL, Chen YC, Wu-Hsieh BA: Modeling the early events of severe acute respiratory syndrome coronavirus infection in vitro. J Virol 2006, 80:2684-2693

27. Zhan J, Deng R, Tang J, Zhang B, Tang Y, Wang JK, Li F, Anderson VM, McNutt MA, Gu J: The spleen as a target in severe acute respiratory syndrome. FASEB J 2006, 20:2321-2328

28. Nicholls JM, Butany J, Poon LL, Chan KH, Beh SL, Poutanen S, Peiris JS, Wong M: Time course and cellular localization of SARS-CoV nucleoprotein and RNA in lungs from fatal cases of SARS. PLoS Med 2006, 3:0222-0229

29. Chan WS, Wu C, Chow SC, Cheung T, To KF, Leung WK, Chan PK, Lee KC, Ng HK, Au DM, Lo AW: Coronaviral hypothetical and structural proteins were found in the intestinal surface enterocytes and pneumocytes of severe acute respiratory syndrome (SARS). Mod Pathol 2005, 18:1432-1439

30. Ding $Y Q$, He L, Zhang QL, Huang ZX, Che XY, Hou JL, Wang HJ, Shen H, Qiu LW, Li ZG, Geng J, Cai JJ, Han HX, Li X, Kang W, Weng DS, Liang P, Jiang SB: Organ distribution of severe acute respiratory syndrome (SARS) associated coronavirus (SARS-CoV) in SARS patients: implications for pathogenesis and virus transmission pathways. J Pathol 2004, 203:622-630

31. To KF, Tong JH, Chan PK, Au FW, Chim SS, Chan KC, Cheung JL, Liu EY, Tse GM, Lo AW, Lo YM, Ng HK: Tissue and cellular tropism of the coronavirus associated with severe acute respiratory syndrome: an in-situ hybridization study of fatal cases. J Pathol 2004, 202:157-163

32. Chow KC, Hsiao CH, Lin TY, Chen CL, Chiou SH: Detection of severe acute respiratory syndrome-associated coronavirus in pneumocytes of the lung. Am J Clin Pathol 2004, 121:574-580

33. Ye J, Zhang B, Xu J, Chang Q, McNutt MA, Korteweg C, Gong E, Gu $\mathrm{J}$ : Molecular pathology in the lungs of severe acute respiratory syndrome patients. Am J Pathol 2007, 170:538-545

34. Jiang Y, Xu J, Zhou C, Wu Z, Zhong S, Liu J, Luo W, Chen T, Qin Q, Deng P: Characterization of cytokine/chemokine profiles of severe acute respiratory syndrome. Am J Respir Crit Care Med 2005, 171:850-857

35. Tang NL, Chan PK, Wong CK, To KF, Wu AK, Sung YM, Hui DS, Sung JJ, Lam CW: Early enhanced expression of interferon-inducible protein-10 (CXCL-10) and other chemokines predicts adverse outcome in severe acute respiratory syndrome. Clin Chem 2005, 51:2333-2340

36. Goldsmith CS, Tatti KM, Ksiazek TG, Rollin PE, Comer JA, Lee WW, Rota PA, Bankamp B, Bellini WJ, Zaki SR: Ultrastructural characterization of SARS coronavirus. Emerg Infect Dis 2004, 10:320-326

37. Farcas GA, Poutanen SM, Mazzulli T, Willey BM, Butany J, Asa SL, Faure $\mathrm{P}$, Akhavan $\mathrm{P}$, Low DE, Kain KC: Fatal severe acute respiratory syndrome is associated with multiorgan involvement by coronavirus. $\mathrm{J}$ Infect Dis 2005, 191:193-197

38. Ng WF, To KF, Lam WW, Ng TK, Lee KC: The comparative pathology of severe acute respiratory syndrome and avian influenza A subtype H5N1-a review. Hum Pathol 2006, 37:381-390

39. Shi X, Gong E, Gao D, Zhang B, Zheng J, Gao Z, Zhong Y, Zou W, Wu B, Fang W, Liao S, Wang S, Xie Z, Lu M, Hou L, Zhong H, Shao H, Li N, Liu C, Pei F, Yang J, Wang Y, Han Z, Shi X, Zhang Q, You J, Zhu $\mathrm{X}, \mathrm{Gu} \mathrm{J}$ : Severe acute respiratory syndrome associated coronavirus is detected in intestinal tissues of fatal cases. Am J Gastroenterol 2005, 100:169-176

40. Hung EC, Chim SS, Chan PK, Chan PK, Tong YK, Ng EK, Chiu RW, Leung CB, Sung JJ, Tam JS, Lo YM: Detection of SARS coronavirus RNA in the cerebrospinal fluid of a patient with severe acute respiratory syndrome. Clin Chem 2003, 49:2108-2109

41. Lau KK, Yu WC, Chu CM, Lau ST, Sheng B, Yuen KY: Possible central nervous system infection by SARS coronavirus. Emerg Infect Dis 2004, 10:342-344

42. Xu J, Zhong S, Liu J, Li L, Li Y, Wu X, Li Z, Deng P, Zhang J, Zhong $N$, Ding $Y$, Jiang $Y$ : Detection of severe acute respiratory syndrome coronavirus in the brain: potential role of the chemokine mig in pathogenesis. Clin Infect Dis 2005, 41:1089-1096

43. Chu KH, Tsang WK, Tang CS, Lam MF, Lai FM, To KF, Fung KS, Tang HL, Yan WW, Chan HW, Lai TS, Tong KL, Lai KN: Acute renal impairment in coronavirus-associated severe acute respiratory syndrome. Kidney Int 2005, 67:698-705

44. Wu VC, Hsueh PR, Lin WC, Huang JW, Tsai HB, Chen YM, Wu KD, and the SARS Research Group of the National Taiwan: Acute renal failure in SARS patients: more than rhabdomyolysis. Nephrol Dial Transplant 2004, 19:3180-3182

45. Xu J, Qi L, Chi X, Yang J, Wei X, Gong E, Peh S, Gu J: Orchitis: a complication of severe acute respiratory syndrome (SARS). Biol Reprod 2006, 74:410-416

46. Leung WK, To KF, Chan PK, Chan HL, Wu AK, Lee N, Yuen KY, Sung $\mathrm{JJ}$ : Enteric involvement of severe acute respiratory syndrome-associated coronavirus infection. Gastroenterology 2003, 125:1011-1017

47. Chan HL, Kwan AC, To KF, Lai ST, Chan PK, Leung WK, Lee N, Wu A, Sung JJ: Clinical significance of hepatic derangement in severe acute respiratory syndrome. World J Gastroenterol 2005, 11:2148-2153

48. Chau TN, Lee KC, Yao H, Tsang TY, Chow TC, Yeung YC, Choi KW, Tso YK, Lau T, Lai ST, Lai CL: SARS-associated viral hepatitis caused by a novel coronavirus: report of three cases. Hepatology 2004 , 39:302-310

49. Wei L, Sun S, Xu CH, Zhang J, Xu Y, Zhu H, Peh SC, Korteweg C, McNutt MA, Gu J: Pathology of the thyroid in severe acute respiratory syndrome. Hum Pathol 2007, 38:95-102

50. Leung TW, Wong KS, Hui AC, To KF, Lai ST, Ng WF, Ng HK: Myopathic changes associated with severe acute respiratory syndrome: a postmortem case series. Arch Neurol 2005, 62:1113-1117

51. Li W, Moore MJ, Vasilieva N, Sui J, Wong SK, Berne MA, Somasundaran M, Sullivan JL, Luzuriaga K, Greenough TC, Choe H, Farzan M: Angiotensin-converting enzyme 2 is a functional receptor for the SARS coronavirus. Nature 2003, 426:450-454

52. Sims AC, Baric RS, Yount B, Burkett SE, Collins PL, Pickles RJ: Severe acute respiratory syndrome coronavirus infection of human ciliated airway epithelia: role of ciliated cells in viral spread in the conducting airways of the lungs. J Virol 2005, 79:15511-15524

53. Hamming I, Timens W, Bulthuis MLC, Lely AT, Navis GJ, Goor HV: Tissue distribution of ACE2 protein, the functional receptor for SARS coronavirus-a first step in understanding SARS pathogenesis. J Pathol 2004, 203:631-637

54. Ren X, Glende J, Al-Falah M, de Vries V, Schwegmann-Wessels C, Qu X, Tan L, Tschernig T, Deng H, Naim HY, Herrler G: Analysis of ACE2 in polarized epithelial cells: surface expression and function as receptor for severe acute respiratory syndrome-associated coronavirus. J Gen Virol 2006, 87:1691-1695

55. Chan PK, To KF, Lo AW, Cheung JL, Chu I, Au FW, Tong JH, Tam JS, Sung JJ, Ng HK: Persistent infection of SARS coronavirus in colonic cells in vitro. J Med Virol 2004, 74:1-7

56. Jia HP, Look DC, Shi L, Hickey M, Pewe L, Netland J, Farzan M, Wohlford-Lenane C, Perlman S, McCray PB: ACE2 receptor expression and severe acute respiratory syndrome coronavirus infection depend on differentiation of human airway epithelia. J Virol 2005, 79:14616-14621

57. Huang IC, Bosch BJ, Li F, Li W, Lee KH, Ghiran S, Vasilieva N, Dermody TS, Harrison SC, Dormitzer PR, Farzan M, Rottier PJ, Choe $\mathrm{H}$ : SARS coronavirus, but not human coronavirus NL63, utilizes cathepsin L to infect ACE2-expressing cells. J Biol Chem 2006, 281:3198-3203

58. Simmons G, Gosalia DN, Rennekamp AJ, Reeves JD, Diamond SL, Bates P: Inhibitors of cathepsin L prevent severe acute respiratory syndrome coronavirus entry. Proc Natl Acad Sci USA 2005, 102:11876-11881

59. Jeffers SA, Tusell SM, Gillim-Ross L, Hemmila EM, Achenbach JE, Babcock GJ, Thomas Jr WD, Thackray LB, Young MD, Mason RJ, Ambrosino DM, Wentworth DE, Demartini JC, Holmes KV: CD209L (L-SIGN) is a receptor for severe acute respiratory syndrome coronavirus. Proc Natl Acad Sci USA 2004, 101:15748-15753

60. Marzi A, Gramberg T, Simmons G, Moller P, Rennekamp AJ, Krumbiegel M, Geier M, Eisemann J, Turza N, Saunier B, Steinkasserer A, Becker S, Bates P, Hofmann H, Pohlmann S: DC-SIGN and DCSIGNR interact with the glycoprotein of Marburg virus and the $S$ protein of severe acute respiratory syndrome coronavirus. J Virol 2004, 78:12090-12095

61. Bashirova AA, Geijtenbeek TB, van Duijnhoven GC, van Vliet SJ, Eilering JB, Martin MP, Wu L, Martin TD, Viebig N, Knolle PA, Kewal- 
Ramani VN, van Kooyk Y, Carrington M: A dendritic cell-specific intercellular adhesion molecule 3-grabbing nonintegrin (DC-SIGN)related protein is highly expressed on human liver sinusoidal endothelial cells and promotes HIV-1 infection. J Exp Med 2001, 193:671-678

62. Soilleux EJ, Morris LS, Leslie G, Chehimi J, Luo Q, Levroney E, Trowsdale J, Montaner LJ, Doms RW, Weissman D, Coleman N, Lee $\mathrm{B}$ : Constitutive and induced expression of DC-SIGN on dendritic cell and macrophage subpopulations in situ and in vitro. J Leukoc Biol 2002, 71:445-457

63. Yang ZY, Huang Y, Ganesh L, Leung K, Kong WP, Schwartz O, Subbarao K, Nabel GJ: pH-dependent entry of severe acute respiratory syndrome coronavirus is mediated by the spike glycoprotein and enhanced by dendritic cell transfer through DC-SIGN. J Virol 2004, 78:5642-5650

64. Imai Y, Kuba K, Rao S, Huan Y, Guo F, Guan B, Yang P, Sarao R, Wada T, Leong-Poi H, Crackower MA, Fukamizu A, Hui CC, Hein L, Uhlig S, Slutsky AS, Jiang C, Penninger JM: Angiotensin-converting enzyme 2 protects from severe acute lung failure. Nature 2005, 436:112-116

65. Kuba K, Imai Y, Rao S, Gao H, Guo F, Guan B, Huan Y, Yang P, Zhang Y, Deng W, Bao L, Zhang B, Liu G, Wang Z, Chappell M, Liu Y, Zheng D, Leibbrandt A, Wada T, Slutsky AS, Liu D, Qin C, Jiang C, Penninger JM: A crucial role of angiotensin converting enzyme 2 (ACE2) in SARS coronavirus-induced lung injury. Nat Med 2005, 11:875-879

66. Yan H, Xiao G, Zhang J, Hu Y, Yuan F, Cole DK, Zheng C, Gao GF: SARS coronavirus induces apoptosis in Vero E6 cells. J Med Virol 2004, 73:323-331

67. Tan YJ, Fielding BC, Goh PY, Shen S, Tan TH, Lim SG, Hong W: Overexpression of $7 \mathrm{a}$, a protein specifically encoded by the severe acute respiratory syndrome coronavirus, induces apoptosis via a caspase-dependent pathway. J Virol 2004, 78:14043-14047

68. Law PT, Wong CH, Au TC, Chuck CP, Kong SK, Chan PK, To KF, Lo AW, Chan JY, Suen YK, Chan HY, Fung KP, Waye MM, Sung JJ, Lo YM, Tsui SK: The 3a protein of severe acute respiratory syndromeassociated coronavirus induces apoptosis in Vero E6 cells. J Gen Virol 2005, 86:1921-1930

69. Yang Y, Xiong Z, Zhang S, Yan Y, Nguyen J, Ng B, Lu H, Brendese $J$, Yang F, Wang H, Yang XF: Bcl-xL inhibits T-cell apoptosis induced by expression of SARS coronavirus $\mathrm{E}$ protein in the absence of growth factors. Biochem J 2005, 392:135-143

70. Ng LF, Hibberd ML, Ooi EE, Tang KF, Neo SY, Tan J, Murthy KR, Vega VB, Chia JM, Liu ET, Ren EC: A human in vitro model system for investigating genome-wide host responses to SARS coronavirus infection. BMC Infect Dis 2004, 4:34

71. Law HK, Cheung CY, Ng HY, Sia SF, Chan YO, Luk W, Nicholls JM, Peiris JS, Lau YL: Chemokine up-regulation in SARS-coronavirusinfected, monocyte-derived human dendritic cells. Blood 2005, 106:2366-2374

72. Cheung CY, Poon LL, Ng IH, Luk W, Sia SF, Wu MH, Chan KH, Yuen KY, Gordon S, Guan Y, Peiris JS: Cytokine responses in severe acute respiratory syndrome coronavirus-infected macrophages in vitro: possible relevance to pathogenesis. J Virol 2005, 79:7819-7826

73. Li L, Wo J, Shao J, Zhu H, Wu N, Li M, Yao H, Hu M, Dennin RH: SARS-coronavirus replicates in mononuclear cells of peripheral blood (PBMCs) from SARS patients. J Clin Virol 2003, 28:239-244

74. Schneider-Schaulies S, Niewiesk S, Schneider-Schaulies J, ter Meulen V: Measles virus induced immunosuppression: targets and effector mechanisms. Curr Mol Med 2001, 1:163-181

75. Geisbert TW, Jahrling PB: Exotic emerging viral diseases: progress and challenges. Nat Med 2004, 10(12 Suppl):110-121

76. Openshaw PJ: Potential therapeutic implications of new insights into respiratory syncytial virus disease. Respir Res 2002, 3(Suppl 1):S15-S20

77. Lee CH, Chen RF, Liu JW, Yeh WT, Chang JC, Liu PM, Eng HL, Lin MC, Yang KD: Altered p38 mitogen-activated protein kinase expression in different leukocytes with increment of immunosuppressive mediators in patients with severe acute respiratory syndrome. $\mathrm{J} \mathrm{Im-}$ munol 2004, 172:7841-7847

78. Huang KJ, Su IJ, Theron M, Wu YC, Lai SK, Liu CC, Lei HY: An interferon- $\gamma$-related cytokine storm in SARS patients. J Med Virol 2005, 75:185-194
79. Wong CK, Lam CW, Wu AK, Ip WK, Lee NL, Chan IH, Lit LC, Hui DS, Chan $\mathrm{MH}$, Chung SS, Sung JJ: Plasma inflammatory cytokines and chemokines in severe acute respiratory syndrome. Clin Exp Immunol 2004, 136:95-103

80. Spiegel M, Pichlmair A, Martinez-Sobrido L, Cros J, Garcia-Sastre, A, Haller $\mathrm{O}$, Weber $\mathrm{F}$ : Inhibition of beta interferon induction by severe acute respiratory syndrome coronavirus suggests a two-step model for activation of interferon regulatory factor 3. J Med Virol2005, 79:2079-2086

81. Tseng CT, Perrone LA, Zhu H, Makino S, Peters CJ: Severe acute respiratory syndrome and the innate immune responses: modulation of effector cell function without productive infection. J Immunol 2005 , 174:7977-7985

82. Medzhitov R, Janeway Jr C: Innate immunity. N Engl J Med 2000, 343:338-344

83. Ip WK, Chan KH, Law HK, Tso GH, Kong EK, Wong WH, To YF, Yung RW, Chow EY, Au KL, Chan EY, Lim W, Jensenius JC, Turner MW, Peiris JS, Lau YL: Mannose-binding lectin in severe acute respiratory syndrome coronavirus infection. J Infect Dis 2005, 191:1697-1704

84. Lin YS, Lin CF, Fang YT, Kuo YM, Liao PC, Yeh TM, Hwa KY, Shieh CC, Yen JH, Wang HJ, Su IJ, Lei HY: Antibody to severe acute respiratory syndrome (SARS)-associated coronavirus spike protein domain 2 cross-reacts with lung epithelial cells and causes cytotoxicity. Clin Exp Immunol 2005, 141:500-508

85. Yang YH, Huang YH, Chuang YH, Peng CM, Wang LC, Lin YT, Chiang BL: Autoantibodies against human epithelial cells and endothelial cells after severe acute respiratory syndrome (SARS)-associated coronavirus infection. J Med Virol 2005, 77:1-7

86. Leung GM, Hedley AJ, Ho LM, Chau P, Wong IO, Thach TQ, Ghani AC, Donnelly CA, Fraser C, Riley S, Ferguson NM, Anderson RM, Tsang T, Leung PY, Wong V, Chan JC, Tsui E, Lo SV, Lam TH: The epidemiology of severe acute respiratory syndrome in the 2003 Hong Kong epidemic: an analysis of all 1755 patients. Ann Intern Med 2004, 141:662-673

87. Booth CM, Matukas LM, Tomlinson GA, Rachlis AR, Rose DB, Dwosh HA, Walmsley SL, Mazzulli T, Avendano M, Derkach P, Ephtimios IE, Kitai I, Mederski BD, Shadowitz SB, Gold WL, Hawryluck LA, Rea E, Chenkin JS, Cescon DW, Poutanen SM, Detsky AS: Clinical features and short-term outcomes of 144 patients with SARS in the greater Toronto area. JAMA 2003, 289:2801-2809

88. Zou Z, Yang Y, Chen J, Xin S, Zhang W, Zhou X, Mao Y, Hu L, Liu D, Chang B, Chang W, Liu Y, Ma X, Wang Y, Liu X: Prognostic factors for severe acute respiratory syndrome: a clinical analysis of 165 cases. Clin Infect Dis 2004, 38:483-489

89. Chan JW, Ng CK, Chan YH, Mok TY, Lee S, Chu SY, Law WL, Lee MP, Li PC: Short term outcome and risk factors for adverse clinical outcomes in adults with severe acute respiratory syndrome (SARS). Thorax 2003, 58:686-689

90. Peiris JS, Chu CM, Cheng VC, Chan KS, Hung IF, Poon LL, Law KI, Tang BS, Hon TY, Chan CS, Chan KH, Ng JS, Zheng BJ, Ng WL, Lai RW, Guan Y, Yuen KY; HKU/UCH SARS Study Group: Clinical progression and viral load in a community outbreak of coronavirusassociated SARS pneumonia: a prospective study. Lancet 2003, 361:1767-1772

91. Lin M, Tseng HK, Trejaut JA, Lee HL, Loo JH, Chu CC, Chen PJ, Su YW, Lim KH, Tsai ZU, Lin RY, Lin RS, Huang CH: Association of HLA class I with severe acute respiratory syndrome coronavirus infection. BMC Med Genet 2003, 4:9

92. Ng MH, Lau KM, Li L, Cheng SH, Chan WY, Hui PK, Zee B, Leung CB, Sung JJ: Association of human-leukocyte-antigen class I ( $\left.\mathrm{B}^{*} 0703\right)$ and class II (DRB1*0301) genotypes with susceptibility and resistance to the development of severe acute respiratory syndrome. $\mathrm{J}$ Infect Dis 2004, 190:515-518

93. Chan VS, Chan KY, Chen Y, Poon LL, Cheung AN, Zheng B, Chan KH, Mak W, Ngan HY, Xu X, Screaton G, Tam PK, Austyn JM, Chan LC, Yip SP, Peiris M, Khoo US, Lin CL: Homozygous L-SIGN (CLEC4M) plays a protective role in SARS coronavirus infection. Nat Genet 2006, 38:38-46

94. Gu J, Taylor RC: The pathogenesis of SARS. Appl Immunohistochem Mol Morphol 2003, 11:281-282 